\title{
An intracellular self protein synthesized in macrophages is presented but fails to induce tolerance
}

\author{
Brigltta Stockinger and Rong Hwa Lin \\ Basel Institute for Immunology, Grenzacherstrasse 487, CH-4058 Basel, Switzerland \\ Key words: C5 deficiency, tolerance, class II MHC restrictıon, $\gamma$-ınterferon, antıgen presentation
}

\begin{abstract}
Mice deficlent for the fifth component of murine complement (C5), unlike normal mice, do not possess the secreted form of $\mathrm{C5}$ in their body fluids and can be readily Immunized to serum-derived normal C5. Although macrophages from C5-deflcient mice do not secrete C5, they synthesize the precursor form (pro-C5). Therefore contact of T cells with autologous pro-C5 presented by macrophages is theoretically possible. We show that macrophages from C5-deficient mice can indeed stimulate a class II restricted C5-specific $T$ cell clone without addition of exogenous C5. Immunization of C5-deficient mice with autologous pro-C5 induces vigorous C5-8pecific $\mathrm{T}$ cell proliferation and pro-C5 is recognized by C5-8pecific $\mathrm{T}$ cells in vitro, demonstrating that this protein falls to Induce tolerance under physiological conditions. Thus, Intracellular pro-C5 is processed and presented by C5-deficient macrophages and can activate $T$ cell clones in vitro, yet is neither immunogenic nor tolerogenic for T cells in vivo.
\end{abstract}

\section{Introduction}

The fifth component of murıne complement (C5) is a self antigen that is normally present in plasma at a concentration of $-10^{-7} M(1)$. The widespread occurrence in the mouse population of a spontaneous mutation affecting synthesis and secretion of $C 5$ has generated a natural model for studies of self tolerance $(2,3)$. Mice deficient for C5 do not possess secreted C5 protein and as a consequence are not tolerant of C5 Immunization with normal serum results in generation of C5-specific antibodies $(2,3)$ and $\mathrm{CD} 4+\mathrm{T}$ cells that recognize $\mathrm{C} 5$ in the context of class II MHC (4).

Tolerance induction presumably involves self molecules expressed by cells in the thymus as well as secreted proteins which can reach the thymus to be presented to developing $T$ cells. In C5-sufficient mice which do not generate anti-C5 $T$ cell responses, endogenous secreted $\mathrm{C} 5$ is processed and presented by antigen-presentıng cells in thymus and periphery (4), allowng Induction and maıntenance of tolerance. Although C5-deficient mice are devoid of secreted $\mathrm{C} 5$, their macrophages (and hepatocytes) synthesize a single-chain precursor molecule (pro-C5) (5). In normal mice pro-C5 is subsequently cleaved and secreted as a disulfide-linked heterodimer (6). A defect at a yet undefined site reduces the rate of synthesis of pro-C5 in C5-deficient macrophages and prevents its modification and secretion $(5,7)$.
The synthesis of pro-C5 in macrophages, which process and present not only exogenous but also endogenous proteins $(8,9)$, raises the question of whether this molecule is presented and recognized by $T$ cells from $C 5$-deficient donors.

In this paper we show that macrophages from C5-deficient mice indeed present their endogenous pro-C5 which can activate T cell clones in vitro. However, T cells in vivo appear to ignore this self antigen so that, as a consequence, neither tolerance nor autommunity is induced

\section{Methods}

Mice

B10.D2/OSn (O) and B10.D2/nSn (N) mice were obtaıned from the Jackson Laboratories, Bar Harbor, ME and maintained in the Basel Institute animal facilities.

\section{$T$ cell prolfferation assays}

Draining lymph nodes from mice immunized in the base of the tail 8-10 days previously were aseptically removed and cell suspensions were prepared. C5-specific prolfieration assays were set up as described (4) Briefly, $4 \times 10^{5}$ responding lymph node cells/well of flat-bottom, 96-well culture plates (Costar) were

Correspondence to B Stockınger, as above

Transmitting editor $\mathrm{E}$ Simpson 
cultured in $0.2 \mathrm{ml}$ total volume of Iscove's modified Dulbecco medium supplemented with $5 \%$ fetal calf serum (FCS; Gibco), $5 \times 10^{-5} \mathrm{M}$ mercaptoethanol, $2 \times 10^{-3} \mathrm{M}$ L-glutamine, and $100 \mu \mathrm{g} / \mathrm{ml}$ gentamycin. Cultures were incubated for 3 days with affınıty-purified C5 antıgen prepared as described (10). For the last $20 \mathrm{~h} 1 \mu \mathrm{Cl} /$ well $\left[{ }^{3} \mathrm{H}\right]$ thymidine was added Cultures were harvested and counted in a liquid scintıllatıon counter.

\section{Preparation of liver extracts}

Liver extracts from $O$ and $N$ were prepared as described (11). Briefly, livers were homogenızed in $11(\mathrm{w} / \mathrm{v})$ PBS containing $1 \mathrm{mM}$ PMSF. They were then spun at $11,000 \mathrm{~g}$ for $30 \mathrm{~m} ı \mathrm{n}$ The supernatants were extracted with chloroform and spun at 10,000 $g$ for $1 \mathrm{~h}$. The resulting supernatants were once more spun at $35,000 \mathrm{~g}$ for $40 \mathrm{~min}$

\section{Precipitation of pro-C5}

Liver extracts were precleaned by addition of proteın $A-$ Sepharose. Pro-C5 in liver extracts was precipitated by addition of $50 \mu \mathrm{g}$ of the $\mathrm{lgG}$ fraction of a polyclonal antı-C5 antiserum per $2 \mathrm{~g}$ original liver input Precipitates were bound by addition of proteın A - Sepharose, washed extensively with PBS containıng $1 \mathrm{mM}$ EDTA, and then emulsified in complete Freund's adjuvant (CFA) For use in culture, pro-C5 from $5 \mathrm{~g}$ of C5-deficient liver was Immunoprecipitated and subsequently eluted with $1 \mathrm{ml}$ of $1 \mathrm{M} \mathrm{KBr}$ and then dialyzed against PBS.

\section{Immunization}

Mice were ımmunized in the base of the tall with $100 \mu$ l antigen preparation emulsified In CFA Serum-derived C5 was prepared by precıpitating the euglobulın fraction of serum containıng $\mathrm{C} 5$ as described (2). Mice received $-25 \mu \mathrm{g} \mathrm{C5}$, assuming a concentration of $50 \mu \mathrm{g} / \mathrm{ml}$ serum.

\section{Establishment of C5-specific $T$ cell clones and hybrids}

The generatıon of C5-specific T cell clones and hybrids has been described in detail (4)

\section{Assay for evaluation of IL-2 production}

The IL-2-dependent T cell line CTLL was cultured at $5 \times 10^{3}$ cells/well with supernatants to be tested for their IL-2 content. Culture medium provided the negative control. After $24 \mathrm{~h}, 1 \mu \mathrm{Cl}$ $\left[{ }^{3} \mathrm{H}\right]$ thymidine was added per well and cultures were harvested $6 \mathrm{~h}$ later

\section{Enrichment of antigen-presenting cells (APC)}

Because of their low buoyant density, APC can be isolated on discontınuous Percoll gradients. Thymus or spleen cell suspensions were prepared and $2 \times 10^{7}$ cells were layered on a gradient consisting of Percoll density 1.074 followed by densities 1062 and 1.05 in $11 \mathrm{ml}$ polycarbonate tubes (Nunc) These tubes were spun at $5000 \mathrm{~g}$ for $20 \mathrm{~min}$ and APC were Isolated from the low-density fraction between densities 1.05 and 1062 . The recoveries were $\sim 7 \%$ from spleen and $0.4 \%$ from thymus.

\section{Preparation of different feeder cell populatıons}

$O$ adherent cells (enriched for macrophages) were prepared by adsorption of spleen cells on $35 \mathrm{~mm}$ tissue culture dishes (Nunc) for $1.5 \mathrm{~h}$ Non-adherent cells were removed by vigorous washıng

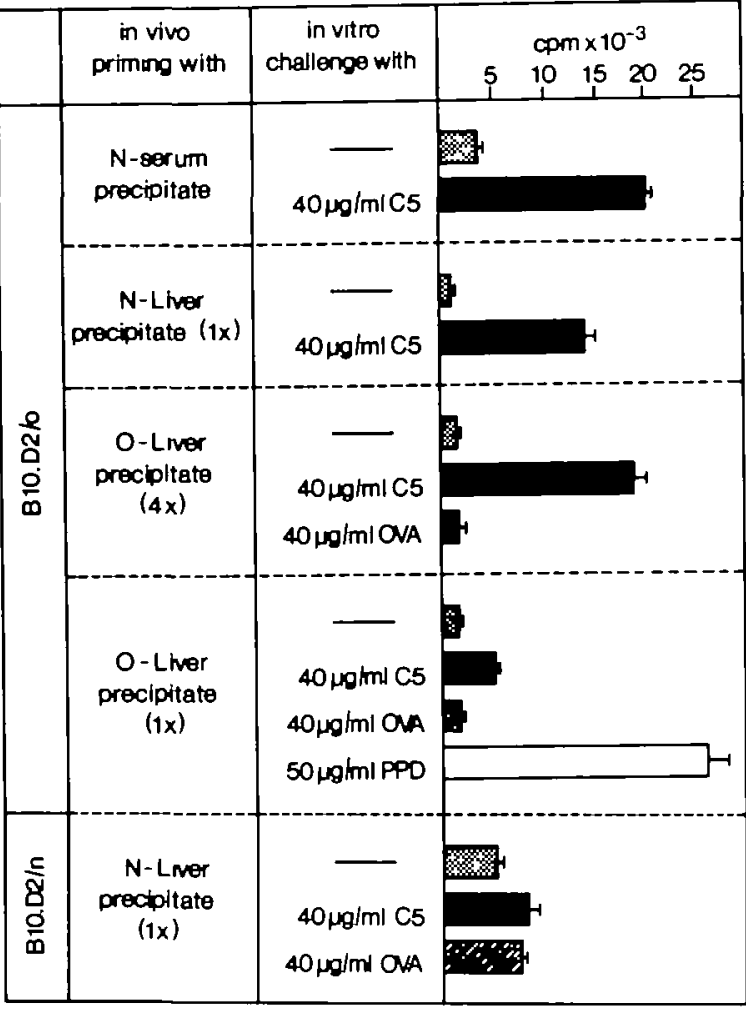

Fig. 1. C5-specific T cell profferation after Immunzzation with precipitates from liver or serum Three $O$ mice per group were immunized in the base of the tait with immunoprecipitates emulsified in CFA of etther $N$ serum equallıng $-10 \mu \mathrm{g} \mathrm{C5/mouse,} \mathrm{N}$ liver equallıng one liver equivalent and O liver equalling four or one liver equivalents, respectrvely $A$ control group of $\mathrm{N}$ mice was injected with $\mathrm{N}$ liver precipitate $\mathrm{Nine}$ days later cells from draining lymph nodes were pooled and assayed for C5-specific proliferation in the presence of $40 \mu \mathrm{g} / \mathrm{ml}$ affinity-purified C5. Control wells received medium or an irrelevant antigen, ovalbumın Tuberculin PPD $\left(50 \mu \mathrm{g} / \mathrm{ml}\right.$. Statens Institute) provided a positive control $\left[{ }^{3} \mathrm{H}\right]$ Thymidine uptake (cpm) after $72 \mathrm{~h}$ of culture is shown.

and adherent cells were subsequently removed by addition of PBS containing $1 \mathrm{mM}$ EDTA

O B cells were prepared by pannıng spleen cells from C5-immune $O$ mice on Petrı dishes (Optlux, Falcon) coated with a 1/1000 dilution of ascrtes from monocional anti-Thy 1.2 antibody 6-68. Non-adherent cells were subsequently subjected to two sequential rounds of adsorption on $35 \mathrm{~mm}$ tissue culture dishes to remove macrophages. B cells were activated with $30 \mu \mathrm{g} / \mathrm{ml}$ LPS for $24 \mathrm{~h}$

O T cells were isolated by nylon wool passage of lymph node cells.

Treatment with $\gamma$-interferon $(\gamma-I F N)$

APC from thymus and spleen were incubated in 96-well, round-bottom tissue culture plates with $250 \mathrm{U} / \mathrm{ml}$ recombınant rat $\gamma$-IFN for $24 \mathrm{~h}$. The medium was then discarded and the plates were washed once with prewarmed culture medium.

Activation of $T$ cell clones with fibroblast $A P C$

Fibroblast APC $\left(1 \times 10^{5} /\right.$ well; ref. 12, CA36.2.1 li) were pulsed with antigen for $6 \mathrm{~h}$ at $37^{\circ} \mathrm{C}$, subsequentty washed and irradiated 
Table 1. T cell reactıvity to pro-C5 in vitro

\begin{tabular}{lcccr}
\hline Responder & Mediuma & pro-C5 & C5 & PR8 vrus \\
\hline C5 hybrid HA2 & $143 \pm 5$ & $45,545 \pm 3218$ & $45,781 \pm 2226$ & $285 \pm 112$ \\
C5 hybrid C8-15 & $11,622 \pm 403$ & $47,386 \pm 1209$ & $42,628 \pm 1083$ & $9432 \pm 1543$ \\
Influenza hybrid BV2-15 & $167 \pm 23$ & $193 \pm 57$ & $225 \pm 167$ & $59,252 \pm 627$ \\
\hline
\end{tabular}

$1 \times 10^{5}$ cells/well from hybrid HA2, C8.15, or BV2.15 were cultured with $1 \times 105 /$ well CA36.2.1 $\mathrm{l}$ fibroblast APC. APC were pulsed tor $6 \mathrm{~h}$ at $37^{\circ} \mathrm{C}$ with either medium or affinity-purified C5 $(5 \mu \mathrm{g} / \mathrm{ml})$ or pro-C5 immunoprecipitated from extracts of $5 \mathrm{~g}$ B10.D2/0 livers Immunoprecipitated material was eluted from Sepharose beads with $1 \mathrm{M} \mathrm{KBr}$ and dialyzed against PBS before addition to the APC After the $6 \mathrm{~h}$ pulse, APC were washed three tımes and irradiated 10,000 rad PR8 vius antıgen $(10 \mathrm{U} / \mathrm{ml})$ was added to irradiated APC together with responder cells rather than pre-pulsed on APC. After $24 \mathrm{~h}$ of culture, $100 \mu$ of supernatant were transferred to a fresh 96-well culture plate containing 5000/well IL-2-dependent CTLL cells for another $24 \mathrm{~h}$ culture penod For the last $6 \mathrm{~h} 1 \mu \mathrm{CI} /$ well [3H]thymıdine was present Results are expressed in mean cpm of thymidine upake $\pm \mathrm{SD}$.

avalues represent $\mathrm{cpm} \times 10^{-3}$

with $10,000 \mathrm{rad}$. They were cultured with $2 \times 10^{4} /$ well cloned $T$ cells for $24 \mathrm{~h}$. One hundred microliters of supernatants were then transferred to wells containing $5 \times 10^{3}$ CTLL cells for assessment of IL-2 production

\section{Immunization with Listeria monocytogenes}

Mice were ımmunızed i $v$ with $5 \times 10^{4}$ live Listeria (a gift from Dr Stefan Kaufmann, Uim)

\section{Results}

T cell reactivity of C5-deficient mice to autologous C5

To test $T$ cell reactivity to autologous pro-C5, liver extracts from C5-deficient B10.D2/O (O) mice and the congenic C5-sufficient strain B10.D2/n (N) were prepared and pro-C5 was precipitated with polyclonal anti-C5 antibody Precipitate from $\mathrm{N}$ and $\mathrm{O}$ liver extracts showed a single band of mol. wt $\sim 180,000$ corresponding to pro-C5 on SDS gels run under reducing conditions. Precipitates from N serum showed the two chains of secreted $\mathrm{C} 5$. The concentration of $\mathrm{O}$ pro-C5 was estımated to be -8 -fold lower than $\mathrm{N}$ pro-C5 (data not shown)

C5-deficient $O$ mice and one group of C5-sufficient $N$ mice were immunized in the base of the tail with precipitates in CFA They either received one liver equivalent of $\mathrm{N}$ or $\mathrm{O}$ or four liver equivalents of $\mathrm{O}$, and $\mathrm{N}$ serum precipitate containing $\sim 10 \mu \mathrm{g} \mathrm{C} 5$

The results presented in Fig. 1 clearly show that immunization with $N$ serum precipitate, $N$ liver precipitate, and $O$ liver precipitate equalling four liver equivalents induced comparable C5-specific proliferation. Primıng with one liver equivalent of $O$, which was estimated to contain - 8-fold less precipitated pro-C5, induced low but detectable proliferatıon. Absence of proliferation to the control antigen ovalbumin, as well as the failure of $\mathrm{N}$ mice immunized with $\mathrm{N}$ liver precipitate to respond to $\mathrm{C} 5$ in culture, excluded potential non-specific activation by protenn $\mathrm{A}$ or antibody in the priming inoculum.

All O mice, with the exception of those immunized with one liver equivalent of $\mathrm{O}$, generated $\mathrm{C5}$-specific antibodies which were predomınantly lgG, (data not shown). No antibody responses to C5 were detected in $\mathrm{N}$ mice regardless of the mode of Immunization. These data provide evidence that $T$ cells from C5-deficient mice are not tolerized to autologous pro-C5.

\section{Pro-C5 from C5-deficient mice is immunogenic in vitro}

Pro-C5 Immunoprecipitated from C5-deficient livers can prime mice for C5-specific responses as shown in the previous

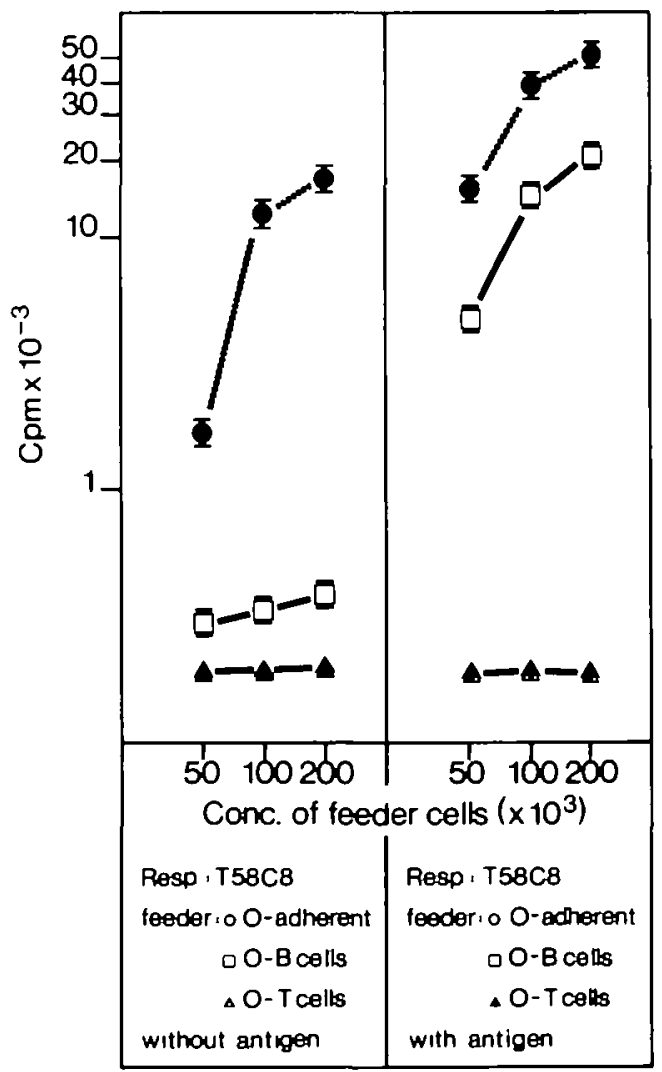

Fig. 2. Protiferative response of clone T58C8 in the presence of different O feeder cells. $2 \times 10^{4}$ cells/well of clone T58C8 were cultured in the presence of various doses of 3000 rad irradiated spleen adherent cells

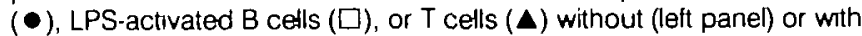
(right panel) $5 \mu \mathrm{g} / \mathrm{ml} \mathrm{C} 5$ for $72 \mathrm{~h} ; 1 \mu \mathrm{Ci} /$ well $\left[{ }^{3} \mathrm{H}\right.$ ]thymidine was added for the last $20 \mathrm{~h}$

experıment. Its ımmunogenıcity in vitro could not be tested in $T$ cell proliferation assays since pro-C5 could not be further purified because the monoclonal antibody used for affinity purification of C5 does not cross-react with intracellular pro-C5.

To circumvent this problem we took advantage of C5-specific T cell hybrids which secrete $\mathrm{LL}-2$ upon culture with I-Ed-bearing APC and C5 (4). For the following experiment we used I.Ed. bearıng fibroblasts (13) which had been supertransfected with the invarıant chain gene (CA36.2.1 li) and were extremely potent 


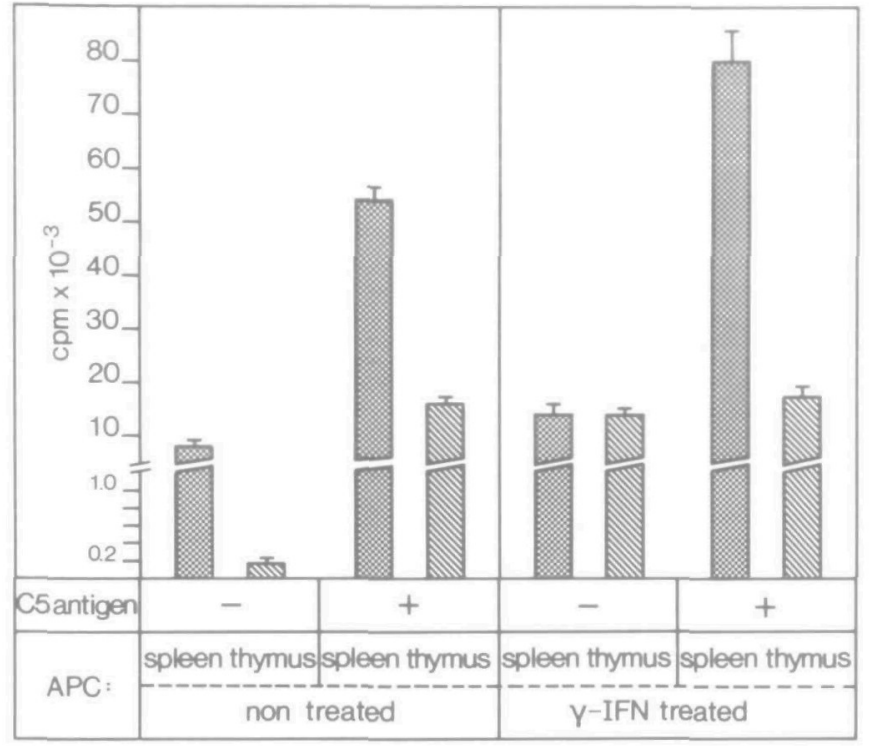

Fig. 3. C5-presenting capacity of spleen and thymus APC before and after treatment with $\gamma$-IFN. APC from thymus and spleen were isolated on discontinuous Percoll gradients. $2 \times 10^{5} \mathrm{APC} /$ well were treated with either medium or $250 \mathrm{U} / \mathrm{ml}$ recombinant rat $\gamma$-IFN in 96-well, round-bottom tissue culture plates for $24 \mathrm{~h} .2 \times 10^{4}$ cells/well of clone T58C 8 were added to either non-treated APC or $\gamma$-IFN-treated APC in the absence or presence of $5 \mu \mathrm{g} / \mathrm{ml} \mathrm{C} 5$ and cultured for $72 \mathrm{~h}$. For the last $20 \mathrm{~h}$, $1 \mu \mathrm{Ci} /$ well $\left[{ }^{3} \mathrm{H}\right]$ thymidine was added to the wells.

APC (12). They were pulsed with either affinity-purified C5 or pro-C5 immunoprecipitated from C5-deficient livers, or C5 precipitated from normal serum and subsequently cultured with the C5-specific T cell hybrids C8-15 and HA2 for $24 \mathrm{~h}$. Table 1 shows that not only normal C5 but also pro-C5 from C5-deficient mice was capable of activating these hybrids for IL-2 secretion. A $T$ cell hybrid specific for influenza hemagglutinin was not stimulated by fibroblasts pulsed with $\mathrm{C} 5$ or pro-C5. We can conclude that $\mathrm{C} 5$-specific $T$ cells are not tolerized to pro-C5 but recognize 'foreign' secreted $\mathrm{C} 5$ just as well as autologous pro-C5 which is still synthesized in C5-deficient mice.

\section{Reactivity of $T$ cells to pro-C5 presented by autologous macrophages}

In vivo autologous pro-C5 does not appear in the circulation of C5-deficient mice and so cannot be processed and presented by every class Il-bearing APC. The only cells that might present pro-C5 in C5-deficient mice are macrophages which synthesize this molecule themselves. Therefore it was of interest to test if $T$ cells from C5-deficient mice could perceive autologous pro-C5 presented by macrophages in the absence of any exogenously added antigen. For these experiments, spleen cells from C5-deficient $\mathrm{O}$ mice were either enriched or depleted of $\mathrm{M} \phi$ and tested for their antigen-presenting capacity to the C5-specific T cell clone T58C8 with or without exogenously added C5.

As shown in Fig. 2, T58C8 proliferated vigorously after culture with $O$ adherent spleen cells that were enriched for macrophages in the presence or absence of C5. In contrast, feeder cells enriched for activated B cells and depleted for adherent cells were excellent APC for exogenously added C5 but they did not stimulate the clone in the absence of C5. Nylon wool-purified T
Table 2. Absence of autoimmune reactivity in Listeria primed mice

\begin{tabular}{llrr}
\hline & Antigen & B10.D2/N & B10.D2/o \\
\hline Exp. 1 & - & 13,252 & 7393 \\
& C5 & 11,824 & 6350 \\
& Listeria & 109,604 & 76,571 \\
Exp. 2 & - & 4769 & 3627 \\
& C5 & 4934 & 4287 \\
& Listeria & 56,544 & 69,967 \\
\hline
\end{tabular}

$\mathrm{O}$ and $\mathrm{N}$ mice were immunized twice with an interval of 1 week with $5 \times 10^{4}$ live Listeria i.v. For experiment 1, spleen and lymph node cells from three mice were pooled 8 days after the second immunization. $5 \times 10^{5}$ responder cells/well of a 96-well culture plate were cultured with $20 \mu \mathrm{g} / \mathrm{ml} \mathrm{C5}$ or $10^{7}$ heat-killed Listeria for $72 \mathrm{~h}$. For the last $20 \mathrm{~h}$, $1 \mu \mathrm{Ci} /$ well thymidine was present. For experiment 2 , spleen and lymph node cells from three mice 8 days after the second immunization were passed over nylon wool columns. $5 \times 10^{5}$ responder cells/well were cultured with $3 \times 105 /$ well 3000 rad irradiated spleen cells from untreated B10.D2/o mice in the presence or absence of C5 or Listeria as stated above.

aValues represent $\mathrm{cpm} \times 10^{-3}$.

cells could not stimulate the clone whether C5 was added or not.

This indicates that autologous intracellular pro-C5 is immunogenic for class II MHC-restricted T cells of C5-deficient mice, not only after exogenous application in CFA but also in its native form presented by macrophages from C5-deficient donors.

These results raise a puzzling paradox: given that pro-C5 presented by autologous macrophages is immunogenic for $T$ cells, why are they not tolerized during thymic differentiation?

\section{C5-presenting capacity of spleen and thymus $A P C$}

Lack of tolerance to pro-C5 might be the consequence of a combination of quantitative effects. Obviously the concentration of pro-C5 is lower in macrophages from C5-deficient mice than in C5-sufficient mice both at the level of mRNA (7) and at the protein level (our experiments with liver extracts).

In addition, class II MHC expression on macrophages is not constitutive (14) and, although macrophages in thymus have been reported to express class II (15), the levels of expression are low (16) so that peptides from pro-C5 might not be appropriately presented to class II MHC-restricted T cells.

Indeed, we found that thymus APC isolated by density gradient centrifugation could not present endogenous pro-C5 to clone T58C8 in contrast to spleen APC. Addition of exogenous C5 induced vigorous proliferation both with spleen and thymus APC, indicating that thymus APC contain dendritic cells that are constitutively class II MHC positive and can present exogenous C5. However, after treatment of thymus and spleen APC with recombinant rat $\gamma$-IFN, which induces MHC class II expression on macrophages (17) prior to addition of the T cell clone, thymus APC were capable of presenting endogenous pro-C5 (Fig. 3). These data support the assumption that the apparent deficiency of class II expression on thymic macrophages under physiological conditions may be one of the reasons that prevent induction of tolerance to pro-C5 during thymic ontogeny of T cells.

Absence of autoimmune anti-C5 reactivity in C5-deficient mice Given the finding that $\mathrm{T}$ cells in $\mathrm{C} 5$-deficient mice are not tolerized 
to pro-C5, one might expect development of autoımmune T cell responses triggered by recognition of class II positive, pro-C5presentıng macrophages in the periphery. However, we have failed to detect any C5-specific T cell reactivity in the absence of prior in vivo primıng with $\mathrm{C} 5$.

It has been stated previously that the magnitude of a $T$ cell response is determined by the product of concentration of antigen and $\mathrm{MHC}$ (18). Increasing one of the two parameters might be a means to stimulate an otherwise non-detectable $T$ cell response. Likewise, we reasoned that up-regulation of MHC class II expression on macrophages might tıp the physiological balance in C5-deficient mice in favor of triggering an autoimmune C5-specific response.

It is well documented that macrophage class II expression is up-regulated in the course of bacterial infection, most notably with intracellular pathogens like Listeria monocytogenes (19), mycobacterium tuberculosis (20), or Trypanosoma cruzi (21). In order to test if Increasing the amount of macrophage class II would allow primıng of C5-specific T cells, we immunized $O$ or $\mathrm{N}$ mice with Listeria monocytogenes and tested for C5-specific $T$ cell proliferation at various time points after secondary immunizatıon. In no case could we detect C5-specific reactıvity. Two representative experıments are shown in Table 2. For experiment 1 we used spleen and lymphocyte cells from Listeriaprimed mice 8 days after the second immunization. For experiment 2 we enriched for T cells and depleted macrophages by passage of spleen and lymph node cells over nylon wool. In the latter case, fresh syngenic spleen cells were added to the cultures to provide purified responder T cells with APC. In both types of experiments we consistently obtained good Listena-specific $T$ cell responses but no C5-specific response.

So it appears that recognition of this intracellular self antigen in vivo does not occur even under conditions that induce strong $\mathrm{MHC}$ class II expression on pro-C5 synthesizıng macrophages.

\section{Discussion}

C5-deficient mice are known not to be tolerant of C5 protein present in serum of normal mice. In this paper we present evidence that lack of tolerance extends to the intracellular precursor molecule pro-C5 which is synthesized but not secreted by C5-deficient macrophages (and hepatocytes).

Immunization with pro-C5-primed C5-deficient mice for C5-specific T cell responses and C5-specific T cells were capable of recognizing pro-C5 in vitro.

It is worth emphasizing that from the point of $T$ cell recognition pro-C5 and C5 probably do not differ since conversion of the single-chain precursor to the functional heterodimer only removes four amino acids and retains the rest of the sequence (22). Deficient pro-C5 may have additional residues recognizable by $T$ cells since it is slightly larger than normal pro-C5 (7). Nevertheless, our data clearly show that $\mathrm{T}$ cell responses to $\mathrm{C} 5$ and deficient pro-C5 overlap

Lack of tolerance to pro-C5 could indicate that this intracellular self protein is normally secluded from recognition by the immune system so that $T$ celis encounter it like a foreign antıgen upon immunization.

However, the finding that some C5-specific T cell clones (represented by $\mathrm{T58C} 8$ ) can recognize autologous pro-C5 in its native form presented by C5-deficient macrophages supports the assumption that this intracellular self antigen can be perceived by class II-restricted T cells. These clones appear to have a high affinity for antigen because they can be activated by 5 - to 10-fold lower doses of antigen presented by fibroblast APC, compared with other clones that do not show stimulation by C5-deficient macrophages in the absence of exogenous antigen (data not shown).

Investıgations of the antıgenic requirements for activation of MHC-restricted T cell responses have provided evidence for the existence of distinct presentation pathways (reviewed in 23) Class I MHC-restricted T cells seem to be preferentially activated by peptıdes generated from endogenous protens which associate with class I MHC (24) while exogenous antigen processed in the low $\mathrm{pH}$ milieu of endosomes seems to associate preferentially with class II molecules to trigger class II-restricted T cells (25). In contradiction to an absolute separation of these pathways is the recent description by Weiss and Bogen (26) of presentation of an endogenous lambda light chain determinant to class II-restricted T cells. Our data describıng recognition of an endogenous, non-secreted protein by class II MHC-restricted cells indicate that at least some pro-C5 peptides have access to the class II presentation pathway.

However, presentation of pro-C5 peptides with class II MHC does not appear to be efficient enough in vivo to ensure induction of tolerance to this self antigen

Furthermore, there are no obvious signs of autoimmunity in C5-deficient mice despite the fact that C5-deficient macrophages from spleen were shown to activate efficiently some C5-specific $T$ cell clones. There are several quantitative factors influencing presentation of this self antigen that probably contribute to the finding that macrophage pro-C5 is ignored by the immune system. Firstly, the amount of antigen avallable to stumulate $T$ cells is low since C5-deficient macrophages synthesize $\sim 10$-fold less pro-C5 than normal macrophages. Secondly, the generally low and regulated expression of class II on macrophages might normally be insufficient to reach the triggering threshold for activation of C5-specific T cells in vivo in support of this assumption, we have shown that thymus APC could not activate a $T$ cell clone in the absence of exogenous antigen unless they were previously treated with $\gamma$-IFN. This effect is most likely due to an increase in class II MHC expression since C5 synthesis in contrast to synthesis of other complement components, like factor $B$ and $C 2$, is not induced by $\gamma-$ IFN (27).

On the other hand, stimulation of class $\|$ expression on macrophages in the periphery following Listeria infections did not result in activation of C5-specific $T$ cells. This would indicate that a mere increase in class II on macrophages, which to some degree would also occur as a consequence of any ongoing ımmune response, does not suffice for recognition of pro-C5 by $T$ cells. However, in view of the recently described interference of Listeria infection with macrophage presentation of other antigens, we cannot exclude the possiblity that presentation of pro-C5 was prevented by Listeria infection (28).

A third quantitative factor influencing presentation of pro-C5 by C5-deficient macrophages could concern the biosynthetic pathway of this defective protein. It is conceivable that the majority of peptides resulting from the degradation of endogenous deficient pro-C5 appear in a cell compartment where they would preferentially associate with class I MHC and only a few peptides 
would have access to the class II presentation route.

The unusual restriction in expression of a self antigen to macrophages that are potential, but not constitutive, APC for class II-restricted $T$ cells offers the possibility to study qualitative and quantitative factors of antigen presentation. Regulation of this function could have crucial implications for development of autormmunity.

\section{Acknowledgements}

We would like to thank Uwe Staerz, Antonı Lanzavecchı, and David Gray for critically reviewing the manuscript. Barbara Hausmann for technical assistance, and Nicole Schoepflin for typing the manuscript We are grateful to Giannı Garotta for supplying us with recombinant rat $\gamma$-interferon The Baset Institute for Immunology was founded and is supported by $F$ Hoffmann-La Roche \& Co Ltd, Basel, Switzerland

\section{Abbreviations}

$\begin{array}{ll}\text { APC } & \text { antigen-presenting cells } \\ \text { CFA } & \text { complete Freund's adjuvant } \\ \text { ConA } & \text { Concanavalin A } \\ \text { C5 } & \text { fifth component of murıne complement } \\ \text { PMSF } & \text { phenylmethylsulfonyl fluorıde }\end{array}$

\section{References}

1 Nilsson, V. R. and Müller-Eberhard, H. J 1967 Deficiency of the fifth component of complement in mice with an inherited complement defect J. Exp Med 125.1

2 Cinader, B, Dubiskı, S., and Wardlaw, A. C 1964 Distribution, inheritance and properties of an antigen, MuB1, and its relation to hemolytic complement. J. Exp Med 120.897.

3 Harris, D. E., Carns, L, Rosen, F. S., and Boret, Y. 1982. A natural model of immunologic tolerance. Tolerance to munne $C 5$ is mediated by $T$ cells, and antigen is required to mantain unresponsiveness. $J$ Exp Med 156567

4 Lin, $\mathrm{A} \mathrm{H}$ and Stockınger, B. 1989 T cell ımmunity or tolerance as a consequence of self antigen presentation. Eur $J \mathrm{Immuno} 19.105$

5 Ool, $Y M$ and Colten, H. R. 1979 Genetic defect in secretion of complement C5 in mice Nature 282.207

6 Ooi, Y. M. and Colten, H. R. 1979. Biosynthesis and post-synthetic modification of a precursor (pro-C5) of the fifth component of mouse complement (C5) J Immunol 1232494

7 Wheat, W H, Wetset, R., Falus, A, Tack, B. F., and Strunk, R C 1987 The fifth component of complement (C5) in the mouse. Analysis of the molecular basis for deficiency J Exp. Med. 1651442

8 Unanue, E R and Allen, P M 1987. The basis for the immunoregulatory role of macrophages and other accessory cells Science 236:551.

9 Lorenz, R. G. and Allen, P M 1988 Direct evidence for functional self proternla complexes in vivo. Proc. Natl Acad. Sci USA 85.5220.
10 Lin, R.H. and Stocknnger, B 1988. Purrication of the fifth component of murine complement $J$. Immunot Methods 115:127

11 Wedderburn, L., Luke, M. L. Edwards, S., Kahan, M. C., Nardi, N., and Mitchison, N. A 1984. Single-step immunosorbent preparation of $F$-protein from mouse liver with conservation of the allo-antigenic stie and determination of concentration in liver and serum. Mol Immunot. 21:979.

12 Stockunger, B., Pessara, U., LIn, R H., Habicht, J., Grez, M., and Koch, N. 1989 A role of la-associated invariant chains in antigen processing and presentation. Cell 56:683.

13 Shastri, N., Malissen, B, and Hood, L 1985. Ia-transfected L-cell fibroblasts present a lysozyme peptide but not the native protein to Iysozyme-specific T cells Proc Natl Acad. SCl. USA 82.5885

14 Unanue, E. R. 1984 Antigen-presenting function of the macrophage. Annu. Rev. Immunol 2.395.

15 Beller, D. I and Unanue, E 1980. la antıgens and antıgen-presentıng function of thymic macrophages. J. Immunol 124:1433.

16 Kyewsk, B A, Rouse, R V, and Kaplan, H. S. 1982 Thymocyte rosettes. multicellular complexes of lymphocytes and bone marrowderived stromal cells in the mouse thymus Proc. Natt Acad Sal USA 79:5646.

17 Steeg, P S., Moore, R. N., Johnson, H M, and Oppenheim, J J 1982 Regulation of murne la antıgen expression by a lymphokıne with immune interferon activity. J. Exp Med. 156.1780.

18 Matıs, L A., Glımcher, L. H , Paul, W. E., and Schwartz, R H. 1983 Magnitude of response of histocompatibility-restncted T-cell clones is a function of the product of the concentrations of antigen and la molecules. Proc. Natl Acad. ScI. USA 80.6019

18 Beller, D I, Kiely, J.-M., and Unanue, E 1980 Regulation of macrophage populations. I Preferential inducton of lanch peritoneal exudates by immunological stimuli $J$ Immunol 124.1426.

20 Ezekowitz, R A , Austyn, J., Stahil, P. D , and Gordon, S 1981. Surface properties of bacillus Calmette-Guenn activated mouse macrophages Reduced expression of mannose-specric endocytosis, Fc receptors and antigen F4/80 accompanies induction of la $J$ Exp. Med 154.60

21 Behbehan, K, Pau, S, and Unanue, E 1981. Marked increase in la-bearing macrophages during trypanosoma cruzı infection. Clin Immunol Immunopathot. 19.190.

22 Wetset, R. A, Ogata, R T, and Tack, B 1987. Pnmary structure of the fitth component of murine complement Biochemistry 26.737

23 Braciale, T. J., Morrison, L. A, Sweetser, M T., Sambrook, J, Gething, $M \mathrm{~J}$, and Braciate, V. L. 1987 Antigen presentation pathways to class I and class II MHC-restricted T lymphocytes Immunol. Rev 98:95.

24 Townsend, A. R. M. Gotch, F. M, and Davey, J 1985. Cytotoxic T cells recognuze fragments of the influenza ructeoprotenn. Cell 42:457.

25 Germain, R N. 1986 The ins and outs of antigen processing and presentation. Nature 322687

26 Weiss, S. and Bogen, B. 1989. B-ymphoma cells process and present their endogenous immunoglobulin to major histocompatibility complex-restricted T cells. Proc. Natl Acad. Sci. USA 86.282.

27 Strunk, R. C., Eidlen, D. M , and Mason, R. J. 1988 Pulmonary alveolar type II epithelial cells synthesize and secrete protens of the classical and alternative complement pathways. $J$ Clin. Invest 811419.

28 Leyva-Cobian, F and Unanue, E R. 1988 Intracellular interference with antıgen presentation. J. Immunol 141:1445. 